$\mathbb{T}$ periodica polytechnica

\author{
Transportation Engineering \\ $40 / 1$ (2012) $39 \sqrt{44}$ \\ doi: 10.3311/pp.tr.2012-1.07 \\ web: http://www.pp.bme.hu/tr \\ (c) Periodica Polytechnica 2012
}

RESEARCH ARTICLE

\section{A new network model for the analysis of air traffic networks}

\author{
Tamás Péter / Krisztián Szabó
}

Received 2012-09-27

\begin{abstract}
In the field of air traffic control it is a significant challenge and source of risk that often maximal performance load is charged against the regions of the airspace. Another problem is the fact that if the air traffic control is inefficient, it brings about substantial excess costs, as well. The article gives a new network model for the analysis of large air traffic networks and provides new opportunities also in the area of control theory. It reviews the relevant macroscopic modeling techniques and the application of the class of positive systems.
\end{abstract}

\section{Keywords}

traffic networks $\cdot$ mathematical modeling and control $\cdot$ nonlinear positive system $\cdot$ macroscopic modeling techniques $\cdot$ internal and external networks simultaneously $\cdot$ new air network model.

\section{Acknowledgement}

The research presented in the article is supported by OTKA, Grant No. CNK 78168.

„TÁMOP-4.2.2.C-11/1/KONV-2012-0012: "Smarter Transport" - IT for co-operative transport system - The Project is supported by the Hungarian Government and co-financed by the European Social Fund"

The research is supported by the TÁMOP-4.2.2/B-10/1-20100009.

\section{Tamás Péter}

Department of Control and Transport Automation, BME, Hungary

e-mail: peter.tamas@mail.bme.hu

\section{Krisztián Szabó}

Computer and Automation Research Institute, Hungarian Academy of Sciences, Hungary

e-mail: szabo.krisztian@sztaki.mta.hu

\section{Introduction}

The use of so-called air corridors has been ceased for nearly twenty years. Currently, the air traffic is taking place on routes and tracks. The main difference between these is that the latter have no lateral dimension.

Modernization and restructuring of the airspace architecture is an ongoing task. Restructuring of the airspace means, in part, that new air routes are established for the arriving or departing aircrafts. This is necessary when the old airspace system cannot withstand the in the meantime heavily increased traffic.

At the same time a very important role falls on the modernization of air traffic control systems and on the training of air traffic controllers, as well, because of the hazards inherent in the new system and due to the improperly trained air traffic controllers, [1]. The major economic challenges require the use of modern control and the development of adequate air traffic network.

Delays in an air traffic network are a major cause of extra costs. Beside the additional costs resulting from fuel usage caused by in-flight delays, additional costs arise from, for example, the missed connections.

Therefore in this area many algorithms aim, at least in part, at the minimization of the delay in air traffic control, for example [2,3].

Another problem is the fact that often maximal air traffic capacity is charged against the regions of the airspace. It is particularly important, therefore, to ensure the controllers control the flights through the crowded sectors safely. For this purpose, it is an important task of air traffic control to achieve a control method, which ensures that the optimal control is fulfilled at the capacity constraints, as well.

A control method with the purpose of minimizing the delay together with capacity constraints has a particular interest in air traffic control. (For example, the wind and weather conditions limit the number of aircrafts that can be routed safely through the affected areas, since the capacity constraints of the airspace regions change in such cases.) 


\section{Research of air traffic control}

The control theory in question applies to systems belonging to the class of positive systems. To this class belong, for example, fluids moving dynamically between reservoirs in a network, where Euler's law of conservation of mass holds, and the basic structure is the interconnected network itself, [4] . Such systems include, for example, any system of reservoirs associated with natural constraints, such as the irrigation networks [5].

These models are used to describe the multitude in different systems, for example, in traffic systems, that manage the flow of cars on the road, or the flow of aircrafts in the airspace and in that the control is performed with groups of computers [6]. The Eulerian model became popular in air traffic flow control problem applications partly because these models are suitable for traditional linear system control planning, as well. For example, linear quadratic control theory has been used in [7]. However, the control defined in this way does not ensure the closed loop system, which also has to remain positive, so additional constraints have to be used to provide a positive reaction. Problem is that this control scheme is only one approach of the flow distribution rates used as control parameter. Some further methods existing in the air traffic flow control include: Eulerian models used to define routes, for example, Le Ny, J. and Balakrishnan, H. (2009), [8] who gave the non-linear control technique based on the Max Weight (maximum weight) principle, or control based on the joint aim of the controlled flights Menon, P.K. et al, (2004) [7].

In the area of air traffic control Arneson, H. and Langbort C. (2009) [9] describe the flow of air traffic across networks in the case airspace sectors using positive conservative systems. In this work the focus is on the design of static control parameters using linear methods. The aim is to minimize the total delay on a single destination network, while satisfying further delay and/or capacity constraints. The flow from a network section can re-enter to other network sectors, including itself. The final sections of the network are the outlets or terminals. Each section of the network must be connected to a terminal, so at least one route must lead from each section of the network to a terminal (i.e. airport). The state of section $\mathrm{i}$ is denoted by $\mathrm{x}_{i}$, which represents all aircraft in this section. It is assumed that the traffic flows with a constant speed in each section and the crossing time in the sections are $\tau_{i}>0$. In some cases, the flow can return (recirculation can occur) to the section from which it was started. Finally, all aircraft involved in the flow will leave the network in a terminal section. The outflows of section $i$ are taking place according to the control parameters $\left\{\beta_{i j}\right\}$. The network is conservative, so any flow that leaves a section should appear in a subsequent section. The authors presented three problems (No.1 delay minimization, No.2 delay minimization, and satisfaction of further delay restrictions, which are specified by integral formula relative to the network status and No.3 satisfaction of capacity constraints) that was used in control design based on controlling static route parameters. A positive conservative system has been applied which represented the flow through the networks. With these techniques, the control of a small air traffic network has been carried out.

The future work will aim at the development of the presented tools according to the control design. This means on the one hand the control of time-dependent control parameters, and on the other hand, the changes of the constraints, as well. Further work on the robust optimization can be useful in this endeavor. Other problem may be the extension of the above and the handling of various multi-criteria goals in air traffic models, for example, the application of the relevant results of Le Ny, J. and Balakrishnan, H., (2009) [8].

\section{Macroscopic modeling and the application of the class of positives systems}

In the foregoing we have seen that dynamic systems can be obtained by the interconnection of liquid material reservoirs in a network, which approach is very effective in the modeling of different land and air traffic flows, as well.

In the case of macroscopic models the traffic is treated as a flow of a medium applying the so-called liquid or gas flow approach. Macroscopic models were studied to describe the traffic flow using the analogy between the traffic and fluid flows as the starting point in [10, 11, 37, 39, 42]

The continuity principle of the traffic flow is based on two relations, one of them is Euler's equation of continuity, which can be expressed as the conservation law for the vehicles and the other is the fundamental equation. The change in traffic flow is determined as a function of some main features such as the vehicle density, the traffic speed and the traffic flow in [43]. These models have developed from the simple linear relationship described in Greenshields, B.D. (1934), to the increasingly sophisticated and complex methods such as [12,13]. The traditional macroscopic modeling is well suitable for network-level analysis.

In the area of macroscopic modeling of traffic processes the concept of the class of positive systems came up naturally.

The first definition of positive systems was given in [14]: A positive system is a system in which the state variables are nonnegative. In the majority of the analyzed traffic processes the original physical meaning of the states meet this requirement. The classic literature on traffic processes sets up in the most cases general linear system of equations, without using the positive qualities of the process. We might think that the properties recognized in the general linear systems are also true for positive systems without any restrictions; however, this is not the case as described in [15]. The controllability and observability conditions of positive systems cannot be clearly derived with methods known from general systems. This problem is particularly true if a non-negative co-domain is required not only for states, but for the actuator signal, as well. Therefore, the description of the traffic processes as purely positive systems is not a trivial 
task from the control theory point of view. The control task in this case means that we need to control the system from a state to another state so that the states take non-negative values also during the state transitions. In this subject matter the description of the systems and controllability was given in the systematizing works of Caccetta, L. and Rumchev, V.G. (2000) [16] and Farina, L. and Rinaldi, S. (2000)[17, 20].

In the publications of Boothby, W.M. (1982)[21] and Sachkov, Y.L. (1997) [22] the following theorem regarding $\boldsymbol{A}$ real matrix applied in control theory can be declared: The system is positive if and only if the $\boldsymbol{A}$ matrix is a Metzler matrix, i.e. the elements outside the main diagonal are non-negative (the elements in the main diagonal and may be arbitrary).

\section{The creation of the new model}

\subsection{The most complex part of the topic - the macroscopic} modeling of land traffic

The deeper understanding of the transport processes is essential for performing modern road traffic design and advanced traffic control. The application of the traditional modeling approach raises a lot of unanswered questions and always struggles with problems of dimensions.

The systems describing the processes of land traffic are large stochastic dynamic systems. Obviously, a road traffic network model is a very complex dynamic system:

- A number of geometric characteristics impose conditions.

- A number of specific control functions operate in the system.

- The parallel lanes have an effect on each other. This interaction, which means to flow over to and to interfere with each other, influences the vehicle density and vehicle speed emerging on the parallel lanes.

- The oncoming vehicles also interact with each other. This interaction prevails naturally in the case of uncertain drivers, but manifests itself mainly in the disruptions due to overtaking, and in the interference due to the lights of oncoming vehicles in the night.

- The defined parking lots and parking lanes beside roads are "foreign elements" of the classic network operation, at the same time the parked vehicles are also interacting with the network sections, arcs, which they are directly linked to. This relationship with time-varying intensity has such an ability to create, for example, peak load by itself on the analyzed network without any traffic received from a defined external network.

- Internal automations concerning the transfer of vehicles operate between the linked network elements. For example, despite the green light the transfer does not take place when the vehicle density is too high on the receiving section, or zero on the transferring section.

- A large number of participants play a role.
- The human factor has significant influence.

- There are many external factors such as seasonal effects, weather, road quality, road width, topography, etc.

However, the basic requirement of the applicable models is efficiency:

- The model must take into account all the elements of the system, which cause real impact during the operation and the neglect of which would distort the results.

- It must be mathematically correct and valid.

- The model must be numerically fast during simulation.

- Real-time control must be achieved.

\subsection{The scientific results obtained from the creation of large road network model}

A very important new structural result from the modeling point of view is that the dynamic model of the road network is made up of the multitude of the same elements and the codomain of each $\mathrm{x}_{i}$ state parameter value is located in the interval of $[0,1]$. Therefore, the parking lots may also be treated as generalized sections of the model and are dynamic components of the network as the lanes, [23-25].

Another important new structural result is that, regardless of the map-graph, a unified hyper-matrix structure can be specified for the mathematical modeling of large-scale road network processes, which for a network located not necessarily in a singly connected domain describes the entire system of relations between network elements (internal-internal, external-internal, internal-external and external-external relations), [24-26]. Péter, T. (2005), Péter, T. and Bokor, J. (2006), Péter, T. (2007.1) and Péter, T. (2007.2).

The new description of the dynamic model of the system is the base for the calculation and control of the system processes. In this context, the general network model describing the internal and external network operation and the positive non-linear differential system of equations describing the internal and external network processes for any domain bounded by a closed curve is given, [28].

The general network model describing the operation of the internal and external networks simultaneously is as follows:

$$
\left[\begin{array}{c}
\dot{x} \\
\dot{s}
\end{array}\right]=\left[\begin{array}{ll}
\langle L\rangle^{-1} & \\
& \langle P\rangle^{-1}
\end{array}\right]\left[\begin{array}{ll}
K_{11}(x, s) & K_{12}(x, s) \\
K_{21}(x, s) & K_{22}(x, s)
\end{array}\right]\left[\begin{array}{c}
x \\
s
\end{array}\right]
$$

Where $\langle L\rangle$ and $\langle P\rangle$ are diagonal matrices containing the length of internal and external network sections:

$$
\langle L\rangle=\left\langle l_{1}, l_{2}, \ldots, l_{n}\right\rangle, \quad\langle P\rangle=\left\langle p_{1}, p_{2}, \ldots, p_{m}\right\rangle
$$

$K_{11}, K_{12}, \quad K_{21}$ and $K_{22}$ denote the internal-internal, the external-internal, the internal-external and the external-external connection matrices, respectively. The physical meaning of the 
matrix elements is connection (transmission) speed. The elements in the main diagonal of $K_{11}$ and $K_{22}$ are 0 or non-negative. All other elements of the matrices are 0 or positive.

$x$ is the state parameter vector of the internal sectors, $s$ is the state parameter vector of the external sectors, $\dot{x}$ is the time derivative of $x$,

$\dot{s}$ is the time derivative of $s$

$$
x=\left[\begin{array}{l}
x_{1}(t) \\
x_{2}(t) \\
\cdot \\
\cdot \\
\cdot \\
x_{n}(t)
\end{array}\right], s=\left[\begin{array}{l}
s_{1}(t) \\
s_{2}(t) \\
\cdot \\
\cdot \\
\cdot \\
s_{m}(t)
\end{array}\right], \dot{x}=\left[\begin{array}{l}
\dot{x}_{1}(t) \\
\dot{x}_{2}(t) \\
\cdot \\
\cdot \\
\cdot \\
\dot{x}_{n}(t)
\end{array}\right], \dot{s}=\left[\begin{array}{l}
\dot{s}_{1}(t) \\
\dot{s}_{2}(t) \\
\cdot \\
\cdot \\
\cdot \\
\dot{s}_{m}(t)
\end{array}\right]
$$

The positive non-linear differential equation system describing the operation of global network processes is given by the generalization of the model in [29,30].

The following result is important from the control point of view: it was shown applying the method of Lyapunov functions that in a domain bounded by an arbitrary closed curve the autonomous system is asymptotically stable. In the case of the non-autonomous system the control law using the Lyapunov function for boundaries was defined, which gives sufficient conditions for the asymptotic stability of the system and is dynamically applicable in the entire domain and in the sub-domains where a critical situation occurs, [31-33]. The control takes into account the vehicle densities of the traffic entering and exiting the domain, [32, 35, 39, -41].

\subsection{Summary of the characteristics applied in the large road network model}

- In our model $0 \leq \mathrm{x}_{i}(\mathrm{t}) \leq 1 ;(\mathrm{i}=1, \ldots, \mathrm{n})$ normalized vehicle density is used as state parameter. The total length of the vehicles in one stage or section is divided by the length of the stage or section. This calculation can also be used in the case of parking lots, so the parking lots are generalized sections of the model, as well.

- The object of the model is a positive non-linear system. In the network the medium flows with variable speed and according to the defined time-dependent distribution factors denoted by $\alpha_{i j}(\mathrm{t})$. The medium is embodied in road vehicles. The speed depends on the vehicle density, the maximum value of which is limited in all sections. In addition, the speed function is influenced by weather and visibility conditions, road geometry, quality and width.

- $\beta_{i j}(\mathrm{t})$ denotes the obstruction $\left(0 \leq \beta_{i j}(\mathrm{t})<1\right)$ or facilitation $(1<$ $\left.\beta_{i j}(\mathrm{t})\right)$ occurring at the transition between certain sections.

- $0 \leq \mathrm{u}_{i j}(\mathrm{t}) \leq 1$ switching function operation takes into account the effect of traffic lights operating at the section transitions.

- Vehicles are exchanged between the parallel running sections (lanes), as well as between parking lots and sections in the network. This transfer is taken into account by the proportionality function $0 \leq \gamma_{i j}(\mathrm{t})$ or $0 \leq \gamma_{i j}\left(\mathrm{x}_{i}(\mathrm{t}), \mathrm{x}_{j}(\mathrm{t}), \mathrm{t}\right)$.

- Internal prohibiting automatisms operate on the network, as well: vehicles cannot be transferred from $j$ to $i$, if $i$ is full, $\mathrm{x}_{i}(\mathrm{t})=1 \Rightarrow \mathrm{S}\left(\mathrm{x}_{i}(\mathrm{t})\right)=0$. Vehicles also cannot be transferred from $\mathrm{j}$ to $\mathrm{i}$, if $\mathrm{j}$ is empty $\mathrm{x}_{j}(\mathrm{t})=0 \Rightarrow \mathrm{E}\left(\mathrm{x}_{j}(\mathrm{t})\right)=0$. These conditions are easy to follow applying the normalized state parameters, which provide that in the model vehicles cannot be taken from empty sections (the density does not enter into the negative range), and also cannot be transferred to sections where the density has already reached 1 .

- The network is analyzed on a not necessarily singly connected domain bounded by a closed curve "G". In the external sections, which are in direct transfer relation with a network section, the normalized traffic density $0 \leq \mathrm{s}_{i}(\mathrm{t}) \leq 1 ;(\mathrm{i}=1, \ldots, \mathrm{m})$ is measured.

- The traffic model is the so-called macroscopic model.

- The mathematical model is a non-linear, non-autonomous differential equation system.

\subsection{The summary of the scientific achievements of the net-} work model used in the field of air traffic modeling

In the field of air traffic control design static route parameters are used to achieve minimized delays, for example, in [9].

The relationship between the sectors is given with a graph with conditions, for example, for the system depicted in Fig. 1 $\mathrm{O}_{1}=\{1,3,4\}, \mathrm{O}_{2}=\{2,3,4\}, \mathrm{O}_{3}=0, \mathrm{O}_{4}=0$. The speed of aircrafts in the domain is constant.

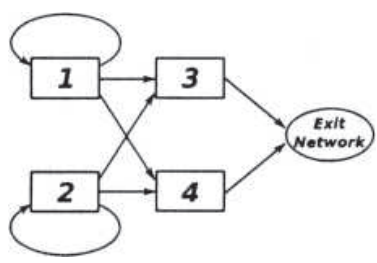

Fig. 1. The airspace network used in the application example described with the graph

\section{The model is based on the following concept:}

- The $0 \leq \mathrm{x}_{i}(\mathrm{t})$ state parameter represents the number of aircrafts present in sector $\mathrm{i}$.

- The traffic model is a macroscopic model.

- The object of the modeling is a linear positive conservative system. The "medium" flows in the network with constant speed and $\beta_{i j}$ distribution factors. The "medium" is embodied by the aircrafts.

- The mathematical model is a linear time-invariant homogeneous differential equation system.

- There are some sections, on which "backflow" is assumed. 
- In the analyzed process with initial state parameters of given values and constant flow velocity, taking into account $\beta_{i j}$ distribution factors the "medium" flows out of the network, so all the aircrafts land at the terminals (airports) eventually.

\section{Optimization objectives:}

- The minimization of total delay, i.e. the landing of the aircrafts should take place in the shortest time by means of the appropriate choice of $\beta_{i j}$ control parameters.

- The minimization of total delay with further delay constraints: e.g. fulfillment of constraints $\left(\beta_{i j}<\mathrm{c}_{i j}\right)$ in the case if some $\beta_{i j}$ factors, or of the condition $\int_{0}^{\infty} \mathrm{x}_{i}(\mathrm{t}) \mathrm{dt}<\gamma_{i}$.

- The minimization of total delay with capacity constraints, for example $\mathbf{x}(\mathrm{t}) \leq \mathbf{b}, \forall \mathrm{t} \geq 0$.

\section{Definition of the new air traffic model}

It is clear that the road networks are very complex compared to the air traffic networks. However, based on the above presented results a universal model has been determined in the case of complex road networks, which can be reconfigured and simplified suitably and is convertible into a new powerful tool for modeling air traffic, as well. At the same time, of course, the air traffic has specialties, which must also be taken into account.

These are the followings:

- The aircraft fills the section with clearances, so its length in the model is much longer than in the reality. This length is the length of the aircraft, and the sum of clearances before and after it.

- The aircraft speed is only slightly dependent on the vehicle density, instead, it depends on external factors occurring at the given time, but these effects are minor. Thus, the speed can be described as constant, together with a superimposed time-dependent perturbation function.

- The internal automatic functions work the same way as on road networks, thus "medium" cannot be taken from empty sections and the application of $\mathrm{E}(\mathrm{x})$ remains. The $\mathrm{S}(\mathrm{x})$ analysis remains, as well, considering, however, that aircrafts cannot be present in a section until the density of the succeeding section falls below 1 . In this case the aircraft, i.e. the material flow should be directed to the pair of the relevant route section defined in the model. This means that the required number of copies of the base graph describing the traffic must be created in the model, and in case of congestion the transition at connection points does not take place on the base graph, but on a copy and at the next connection point the transition returns to the base graph, if it is possible. The model, in fact, is composed of the base graph and of the set of its copies. This corresponds to the real world situation as the air traffic control takes place in common practice. It occurs sometimes that two aircrafts flying close to each other along the same route want to travel at the same altitude. In this case, the air traffic controller who wants to keep the required separation offers level change primarily. If it is agreed, which is usually true, there is no need for speed restriction. If the other flight levels or altitudes are occupied, then the crew may be asked to maintain a certain speed. For example, if the normal cruising speed is of Mach 0.78 , the air traffic controller directs the preceding aircraft to maintain Mach 0.78 or more and the succeeding aircraft to maintain Mach 0.78 or less. If the air traffic controller wants to increase the separation, he/she may reduce or increase the speed of aircrafts, but in almost every case by a maximum of Mach 0.02 deviation from the optimum, which represents only $2.6 \%$ in speed change. The optimum speed is defined principally by the aircraft type, weight and Cost Index. The air traffic controllers are informed about this value. About half of all flights departing from or arriving to Budapest fly in crowded airspace (e.g. Rhein, Maastricht, Langen, London FIR). The pilots' experience shows that in case of approximately $5-10 \%$ of all flights speed restrictions requested by air traffic controllers occur en route.

- Material flow distribution and intensity function work, taking into account the former, the same way as in the road traffic model.

- Interferences can occur during transitions; however, their limit must be analyzed.

- There is no traffic light signal in the traditional sense, however, that can be solved by the air traffic control in such a way that the control is performed on a copy of the section in the model in connection with the $S(x)$ analysis.

\section{Summary}

The work presented here served as a basis for defining a new air traffic model. We have shown that the new model developed for complex road networks Péter, T. (2008)[28] is reconfigurable for air traffic models, as well [36]. So there is a universal network model, which is a powerful new tool not only for road networks, but also in the field of air traffic network modeling and has all the specialties, which must be taken into account in case of the air traffic networks.

With the model the dynamic operation of the air traffic network, specifically the basic questions of network development and management regarding the processes in a network, existing or under development, can be examined. We pointed out that the use of traditional modeling approach raises many unanswered questions and struggles always with size problems. The situation is made more difficult by the fact that the traffic network is very complex and is characterized by different rules, geometric data, seasonality, etc. The aim of the research was to point out that, instead of the application of the traditional map-graph approach, the development of a new model became possible, which leads to the theory of positive non-linear systems in the 
field of mathematics. By the help of that the solution of large network problems and the application of new control options can be obtained (the control principle and optimization using the Lyapunov function is feasible). Analyses can be carried out to check if the network complies with the criteria of sustainable development now, or will do following the development.

\section{References}

1 Szabó K, Szabó G, Renner P., Emberi hibamodellezés alkalmazása a légiközlekedési kockázatelemzésekben., Közlekedéstudományi szemle $\mathbf{1 5}$ (2009), no. 5, 29-36.

2 Bertsimas D, Patterson S. S., The air traffic flow management problem with enroute capacities., Operations Research 46 (1998), no. 3, 406-422.

3 Krozel J, Jakobovits R, Penny S, An algorithmic approach for airspace How progiams, Air Traffic Control Quartelly 14 (2006), no. 3, 203-229.

4 Bastin G, Stabikty and Stabihzation of Nonhnear Systems, Lecture Notes in Control and Information Sciences. Chapter Issues in Modeling and Control of Mass-balanced Systems 53-74, 1999.

5 Cantoni M, Weyer E, Li Y, Ooi S K, Mareels I, Ryan M, Control of largescale irrigation networks, Proceedings of the IEEE 95 (2007), no. 1, 75-91.

6 Fu Y, Wang H, Lu C, Chandra R S, Distributed utilization control for realtime clusters with load balancing, 2006.

7 Menon P K, Sweriduk G D, Bilimoria K D, New approach for modeling, analysis, and control of air traffic How, Journal of Guidance, Control, and Dynamics 27 (2004), no. 5, 737-744.

8 Le Ny J, Balakirshnan H, Distributed feedback control for an Eulerian model of the National Airspace System, 2009. Accepted for presentation at American Control Conference.

9 Arneson H, Langbort C, Linear Programming Based Routing Design for a Class of Positive Systems with integral and Capacity Constraints, Proceedings of the 1st IFAC Workshop on Estimation and Control of Networked Systems (Sept. 24-26, 2009).

10 Lighthill M. J, Whitham G. B, On kinetic waves. I: Flood movement in long rivers. II: A theory of traffic flow on long crowed roads., Proceedings Royal Society, 1955, pp. 281-345.

11 Ashton W D, The Theory of Road Traffic Flow, Methu-hen and CO LTD, London, 1966.

12 Greenshields B. D, A study of traffic capacity. Proceedings of the highway Research Board 14 (1934), 448-477.

13 Greenberg H, An Analysis of Traffic Flow, Operations Research 7 (1959), 79-85.

14 Luenberger D, Introduction to Dynamics Systems, Wiley, New York, 1979.

15 Varga I, Közúti folyamatok paramétereinek modell alapú becslése és forgalomfüggó irányítása, 2007. PhD Értekezés, Budapesti Múszaki és Gazdaságtudományi Egyetem.

16 Caccetta L, Rumchev V G, A survey of reachability and controllability for positive linear systems, Annals of Operations Research 98 (2000), 101-122.

17 Farina L, Rinaldi S, Positive Linear Systems Theory and Applications, John Wiley \&; Sons, Inc., 2000.

18 Bacciotti A, On the positive orthant controllability of two-dimensional bilinear systems, Sys. Control Lett. 3 (1983), 53-55.

19 Coxson P. G, Shapiro H, Positive input reachability and controllability of positive systems, Linear Algebra and its Applications 94 (1987), 35-53.

20 Valcher M E, Controllability and reachability criteria for discrete-time positive systems, International Journal of Control 65 (1996), no. 3, 511-536.

21 Boothby W M, Somé comments on positive orthant controllability of bilinear systems, SIAM J. Control Optim. 20 (1982), 634-644.

22 Sachkov Y L, On positive orthant controllability of bilinear systems in small codi-mensions, SIAM J. Control Optim. 35 (1997), 29-35.
23 Péter T, Bokor J, Nagyméretû közúti közlekedési hálózatok nemlineáris modelljének kapcsolati hipermátrixa, A jövő jármúvei, 2007, pp. 16-21.

24 Péter T, Nagyméretú nemlineáris közlekedési hálózatok modellezése, Közlekedéstudományi szemle 17 (2007), 322-331.

25 Péter T, Nagyméretü közúti közlekedési hálózatok analízise, http://www. kitt.bmf.hu/mmaws/index.html MMA „Innováció és fenntartható felszíni közlekedés" - Konferencia, 2007. szeptember 4-5-6 Budapest, BMF.

26 Péter T, Intelligens közlekedési rendszerek és jármúkontroll. Elôirások a közlekedés biztonságának növelésére, 1-465. Magyar Mérnökakadémia Symposium. Bp. 2005.

27 Péter T, Bokor J, Jármüforgalmi rendszerek modellezése és irányításának kutatása, A jövő jármúve ( 2006), 19-23.

28 Péter T, Tetszóleges méretü nemlineáris közúti közlekedési hálózatok modellezése speciális hálózati gráffal, amelyben a gráf csúcsai általánosított szakaszok, a gráf élei a csúcsok közötti kooperálót leíró dinamikus relációk, A jövő jármúve, III:(3-4) (2008), 26-29.

29 Péter T, Csomópontok optimális múködtetése közúti közlekedési hálózatban, a matematikai modell tárgyalása, Közlekedéstudományi szemle 9 (2011), 27-33.

30 Péter T, Csomópontok optimális múködtetése közúti közlekedési hálózatban, a számítási eredmények vizsgálata, Közlekedéstudományi szemle LX (2011), 4-14.

31 Péter T, Jármüforgalmi rendszerek modellezése és irányítása, célok, kutatási területek és eredmények, A jövô jármúve IV:(1-2) (2009), 59-78.

32 Péter T, Bokor J, Modeling road traffic networks for control, Annual international conference on network technologies \& communications: NTC 2010. Thailand, 2010.11.30-2010.11.30., 2010, pp. 18-22.

33 Péter T, Bokor J, New road traffic networks models for control, GSTF International Journal on Computing 1 ( February 2011), no. 2, 227-232, DOI 10.5176_2010-2283_1.2.65.

34 Péter T, A globális közúti hálózati modell és alkalmazása az intelligens hálózatok létrehozásánál, a BME kutatóegyetemi programjában, 8-19. Budapest, IFFK 2011. aug.29-31. Paper 03.

35 Péter T, Fülep T, Bede Z., The application of a new principled optimal control for the dynamic change of the road network graph structure and the analysis of risk factors, 13th EAEC European Automotive Congress 13th16th June 2011. Valencia - Spain, 2011.

36 Péter T, Szabó K, Új hálózati modell, nagyméretú légiforgalmi hálózatok vizsgálatára, Közlekedéstudományi szemle 4 ( 2012), 46-54.

37 Peter T, Modeling Nonlinear Road Traffic Networks for junction control, International Journal of Applied Mathematics and Computer Science (AMCS) 22 (2012), no. 3, 723-732, DOI 10.2478/v10006-012-0054-1.

38 Bede Zs., Péter T., The development of large traffic network model, Periodica Polytechnica-Transp. Eng. 39 (2011), no. (1-2), 3-5.

39 Bede Zs., Péter T, The mathematical modeling of Reversible Lane System, Periodica Polytechnica-Transportation Engineering 39 (2011), no. (1-2), 7 10.

40 Bede Zs., Szabó G, Péter T, Optimalization of road traffic with the applied of reversible direction lanes, Periodica Polytechnica-Transportation Engineering 38 (2010), no. (1-2), 3-8.

41 Bede Zs., Péter T, The Extraction of Unique Velocity Processes from a Macro Model, Periodica Polytechnica-Transportation Engineering 38 (2010), no. (1-2), 114-121.

42 Bécsi T, Péter T, Development and Evalution of a Fuzzy-based Microscopic Vehicle-following Modell, Periodica Polytechnica-Transportation Engineering 36 (2008), no. (1-2), 15-19.

43 Bécsi T, Péter T, A Mixture of Distributions Background Model for Traffic Video Surveillance, Periodica Polytechnica-Transportation Engineering 34 (2006), no. (1-2), 109-117. 